\title{
A Review of Bank Liquidations and Consolidations in Nigerian Banks
}

\author{
Dr. Aderonke Tayo-Tiwo, \\ Walden University, Minnesota, USA
}

Doi:10.19044/esj.2020.v16n25p160 URL:http://dx.doi.org/10.19044/esj.2020.v16n25p160

\begin{abstract}
Since the emergence of banks in Nigeria in 1892, the Nigerian Banking sector has undergone a restructuring series. Before the 2006 banking consolidation exercise, many banks have gone under primarily due to poor management and inadequate financial reporting. The consolidation of banks in 2006 became necessary to forestall the sector's systemic collapse since many of the banks were distressed and unable to meet their customers' expectations. This qualitative review of the Nigerian banks focused on what transpired in the sector from 2006 to date. Archival and content analysis methods were used in the data collection and analysis process mainly because some banks have been liquidated while others have been merged or acquired by other banks. Findings revealed that some banks that survived the post-2006 consolidation exercise had been liquidated; some have merged with others while the banks are still operating as standalone. The CBN has introduced the bridge banks' concept to acquire and manage distressed banks pending new buyers' time. The amended code of corporate governance of 2016 has drastically improved the CBN's regulatory and monitoring activities. Accordingly, the CBN is better equipped. Lasting measures are in place to forestall any unanticipated disruptions in the Nigerian banking sector.
\end{abstract}

Keywords: Consolidation, Nigerian Banks, Mergers and Acquisitions, Corporate Governance and Bridge Banks

\section{Introduction}

Nigeria gained her independence from the British in 1960. Banking activities in the country commenced in 1892with the creation of the first Nigerian bank, the African Banking Corporation. The second bank, created in 1894, was the First Bank of Nigeria, formerly Bank of British West Africa (Osemeke\&Adegbite, 2016). At that time, banking activities took care of the businesses of the British agencies and companies in Nigeria in charge of shipping and trade activities. 
In 1952, five other banks began to operate in the country. The banks were the Bank of British West Africa, Barclay Bank and French Bank (foreign banks), and two local banks, namely the National Bank of Nigeria and the African Continental Bank (Adegbite, 2012). The local banks served the Nigerian populace's needs while the foreign banks took care of the concerns of the expatriates. More banks emerged after that, including the Industrial Bank, Agbonmagbe (now Wema Bank), and other commercial banks. Most of these banks folded up no sooner than they were established. Ikpefan and Ojeka (2013) noted that uncoordinated practices and poor record-keeping were responsible for the banks' failure.

To streamline and coordinate the banks' activities, the Banking Ordinance of 1952 was enacted (Jakada\&Inusa, 2014). However, the banks did not adhere rigidly to the requirements of the ordinance. Therefore, the period spanning 1892 to 1952 was the era of free banking in Nigeria because of the absence of sustainable banking legislation. The CBN, the regulatory agency, was established in 1959, and the first banking Act was promulgated in July 1959.

Between 1959 and 1989, in-depth deregulation of the economy occurred because of the structural adjustment program embarked upon in the country that led to further deregulation of the Banking industry. As a result, several new banking institutions and other deposit-taking agencies came into being. Some of the banks were the People's Bank, Federal Mortgage Bank, finance houses, and discount houses (Jakada\&Inusa, 2014).

The government created the Peoples Bank and Mortgage Bank to take care of the people's mortgage needs. In 1988, the rise in banking activities in the country led to the emergence of the Nigerian deposit insurance corporation (NDIC), to support the CBN in carrying out supervisory activities. Specifically, the NDIC ensures safe banking service nationwide, carries out insurance on the banks' deposits, and renders support in the CBN's general supervisory role.

During this era, the licensed commercial banks authorized share capital was as low as $\mathrm{N} 2$ billion as of 1988, making it easy for many merchants without the prerequisite banking experiences to obtain banking licenses to support their businesses. As a result, uncoordinated and spurious practices became the order of the day, and most banks' share capital dwindled. It resulted in some banks' inability to meet contractual obligations and refund depositors' funds (Tayo-Tiwo, 2020). This was the beginning of the turbulent banking crisis in Nigeria. A crisis of confidence in the banks ensued, and the banking populace began to lose interest in the banks.

In a bid to forestall a systemic collapse of the banking industry and its crucial role in the economy, the regulatory authority, the $\mathrm{CBN}$, conducted an extensive review of inherent risks in all the banks operating in the country 
(Tayo-Tiwo, 2020). The result was the radical consolidation of the banks in 2006 and an upward review of banks' share capital. The Central Bank categorized the banks into three regional commercial banks, national commercial banks, and commercial banks with international branches. Each category had different share capital requirements. For regional commercial banks, the share capital was N10billion, N25billion for National commercial banks, and N50billion for commercial banks with international branches (CBN Circular 01, 2010).

Regional commercial Banks had licenses to carry out banking activities within six to twelve states in the country and not more than two geopolitical zones, including the federal territory, Abuja. National commercial banks could establish branches and carry out banking activities all over the thirty-six states in the country and the federal capital, Abuja. A commercial bank with international banking license authorization could operate in all the thirty-six states and Abuja and can establish offshore offices in any country it chooses subject to the CBN (CBN Circular 01, 2010).

Bank failures and liquidation have been a persistent problem in Nigeria since the banks' emergence in 1892. The study provides an in-depth review of the banking sector's banking consolidations in Nigeria, its challenges, and an assessment of the CBN bridge bank model. Consequently, this paper examines the history and causes of bank failures in Nigeria by looking at the genesis of the banking institution in Nigeria and the expanded role of the $\mathrm{CBN}$ to ensure the sector's stability.

\section{Purpose of the Study}

The issue of bank failures and liquidation has been a persistent problem in Nigeria since the banks' emergence in 1892. The study provides an in-depth review of the banking sector's banking consolidations in Nigeria, its challenges, and an assessment of the CBN bridge bank model. Consequently, this paper examines the history and causes of bank failures in Nigeria by looking at the genesis of the banking institution in Nigeria and the expanded role of the $\mathrm{CBN}$ to ensure the sector's stability.

\section{Data Collection Method}

In carrying out this review, the researcher reviewed banking sector data and the website of the Central Bank of Nigeria and the Nigeria Deposit Insurance Corporation. The study employed a content analysis method as prescribed by (Okafor 2019; Wilson, 2011). Content analysis methods are typically used to analyze qualitative or quantitative data containing written, verbal, or visual documentation dating back to the 1950s (White \& Marsh, 2006). Using this method, data from the Central Bank of Nigeria and Nigeria Deposit Insurance Corporation publications were collected and replicated to 
make valid inferences. Archival data were obtained and analyzed to assess the banking industry's trajectory and subsequent measures to arrest the perennial bank failures in Nigeria.

\section{Incidences of Bank failures in Nigeria}

The issue of bank failures and liquidation has been a persistent problem in Nigeria since the banks' emergence in 1892. Most of the pioneer banks failed because of uncoordinated activities, mismanagement, and shoddy reporting among the staff and the directors of the banks (Afolabi \& Dare, 2015). The advent of the regulatory agency, the Central Bank of Nigeria, CBN, in 1959 led to standardization in the banking sector (Okafor, 2019). Accordingly, the Nigerian banking system witnessed tremendous growth until the erato2006 when the bank consolidation occurred. To instill financial discipline in the banking industry, the CBN introduced the code of corporate governance immediately in 2006(Umanholen, 2015). As a result, the number of banks and discount houses operating in the country reduced to 26 from 87 (Okafor \&Fadul, 2019).

Table 1: Closed and Liquidated Financial Institutions on or before 2006

\begin{tabular}{|c|ll|}
\hline S/NO & NAME OF BANK UNDER LIQUIDATION & DATE OF CLOSURE \\
\hline $\mathbf{1}$ & Abacus Merchant Bank Ltd & Jan. 16, 1998 \\
$\mathbf{2}$ & ABC Merchant Bank Ltd & Jan. 16, 1998 \\
$\mathbf{3}$ & African Express Bank Ltd & Jan. 16, 2006 \\
$\mathbf{5}$ & Allied Bank of Nigeria Plc & Jan. 16, 1998 \\
$\mathbf{6}$ & AllStates Trust Bank Plc. & Jan. 16, 1998 \\
$\mathbf{7}$ & Amicable Bank of Nigeria Plc. & Sept. 08, 1994 \\
$\mathbf{8}$ & Assurance Bank of Nigeria Plc & Jan. 16, 1998 \\
$\mathbf{9}$ & Century Merchant Bank Ltd. & Jan. 16, 2006 \\
$\mathbf{1 0}$ & City Express Bank Plc & Jan. 16, 1998 \\
$\mathbf{1 1}$ & Commerce Bank Plc & Jan. 16, 2006 \\
$\mathbf{1 2}$ & Commercial Trust Bank Ltd & Jan. 16, 1998 \\
$\mathbf{1 3}$ & Continental Merchant Bank Plc & Jan. 16, 1998 \\
$\mathbf{1 4}$ & Cooperative and Commerce Bank Plc & Jan. 16, 1998 \\
$\mathbf{1 5}$ & Credit Bank Nig. Ltd & Jan. 16, 1998 \\
$\mathbf{1 6}$ & Crown Merchant Bank Ltd. & Jan. 16, 1998 \\
$\mathbf{1 7}$ & Financial Merchant Bank Ltd. & Jan. 16, 1998 \\
$\mathbf{1 8}$ & Great Merchant Bank Ltd. & Jan. 21, 1994 \\
$\mathbf{1 9}$ & Group Merchant Bank Ltd. & Jan. 16, 1998 \\
$\mathbf{2 0}$ & Gulf Bank Ltd & Jan. 16, 1998 \\
$\mathbf{2 1}$ & Hallmark Bank Plc & Jan. 16, 2006 \\
$\mathbf{2 2}$ & Highland Bank of Nig Plc & Jan. 16, 2006 \\
$\mathbf{2 3}$ & ICON Ltd. (Merchant Bankers) & Jan. 16, 1998 \\
$\mathbf{2 4}$ & Ivory Merchant Bank Ltd. & Jan. 16, 1998 \\
$\mathbf{2 5}$ & Kapital Merchant Bank Ltd. & Dec. 22, 2000 \\
\cline { 2 - 3 } & & Jan. 21, 1994 \\
\hline
\end{tabular}


Lead Bank Plc

Lobi Bank of Nig. Ltd.

Jan. 16, 2006

Mercantile Bank of Nig. Plc.

Jan. 16, 1998

29

Merchant Bank of Africa Ltd.

Jan. 16, 1998

30

Metropolitan Bank Ltd.

Jan. 16, 1998

Nigeria Merchant Bank Ltd.

Jan. 16, 2006

31

North-South Bank Nig. Plc.

Jan. 16, 1998

Pan African Bank Ltd.

Pinnacle Commercial Bank Ltd.

Jan. 16, 1998

Jan. 16, 1998

Premier Commercial Bank Ltd

Jan. 16, 1998

Prime Merchant Bank Ltd.

Dec. 22, 2000

36

37

38

Progress Bank Ltd.

Jan. 16, 1998

Republic Bank Ltd

Jan. 16, 1998

39

Rims Merchant Bank Ltd.

June 29, 1995

Dec. 22, 2000

40

41

42

Royal Merchant Bank Ltd.

Jan. 16, 1998

Trade Bank Plc

United Commercial Bank Ltd.

Jan. 16, 2006

Sept. 8, 1994

Victory Merchant Bank Ltd.

Jan. 16, 1998

Eagle Bank Plc.

45

Liberty Bank Plc.

Jan. 16, 2006

Jan. 16, 2006

Source: CBN Circular 2006

The above list of closed financial institutions excludesall the names of the banks whose licenses were revoked by the Central Bank of Nigeria.

\section{Banks Consolidations in Other Countries}

The value of an organization, especially a financial institution depends largely on the present discounted value or the anticipated future profits (Makanjuola, 2015). Historically mergers of institutions lead to increased size and higher profits because of a reduction in operational costs (Kolapo, Ajayi \&Aluko, 2016). Because of the increased size, mergers allows for a larger market share and increased visibility (Makanjuola, 2015).

The role played by government policies can either facilitate or hinder consolidation. In the USA, government agencies provide financial support to healthy banks that acquire ailing banks during the crisis of 1980s and early 1990s (Hosono, Sakai \& Kotaro, 2007). In countries like Japan, France, Scandinavia, the financial crisis of the 1990s contributed to the accelerated changes and growth in the banking industry (Hosono, Sakai \& Kotaro, 2007).

\section{Bank Consolidation in Japan}

In Japan, during the World War crisis of the 1990s, government funds were used to support consolidation in an effort to create a national bank that could compete effectively in the global banking industry (Peek \& Rosengren, 2005). Japan is one of the world's largest industrialized nations. The major 
financial institutions in the country are commercial banks, foreign exchange companies, securities, and capital market. The government owned institutions inject funds to the economy to maintain liquidity and to maintain the monetary policy.

The establishment of financial institutions in Japan dates back to 1880 with the creation of the Yokohama Specie Bank, which was later, renamed the Bank of Tokyo (Hosono, Sakai \& Kotaro, 2007). Toward the end of 1880, the Mitsubishi Bank came into being mainly the financier of the Mitsubishi heavy industry. In 1996, the Mitsubishi Bank merged with the Bank of Tokyo in 1996 (Hosono,Sakai\& Kotaro, 2007). Hitherto, the bank of Tokyo was set up the Japanese government solely to act as the Japanese International Bank to the outside world solely responsible for trading in Yen, the nation's official currency. However, after the Second World War, most Japanese banks became moribund resulting in the failure of many banks notably three large financial institutions namely Hokkaido Takushoku Bank, Nippon Bank, and Long term Credit Bank of Japan (Peek \& Rosengren, 2005).

To salvage the situation the Japanese regulatory authorities introduced prompt corrective action in 1998 by applying stringent accounting standards and the implementation of Basel capital standards as well as the recapitalization of some banks. Several land scale mergers had taken place resulting in the creation of very large banks like Mitsubishi UFJ, Mizuho and Mitsui-Sumitomo banks (Kano \& Tsutsui, 2003). The Mitsubishi UFJ Financial Group is the largest bank in Japan with an asset base of \$1.7 trillion trailing after the world's biggest bank: Citigroup with $\$ 2.4$ trillion in assets (Hosono, Sakai \& Kotaro, 2007).

\section{Findings}

\section{Nigerian Banks Post 2006 Consolidation Exercise}

After the consolidation of the banks, the names of the survivingtwentysix banks were; United Bank for Africa (UBA), First Bank, Union Bank, Guaranty Trust Bank, Zenith Bank, Intercontinental Bank, Standard Chartered Bank, Oceanic Bank, Access Bank, Eco Bank, Equatorial Trust Bank and Sterling Bank. Others include NIB/ Citibank, Fidelity Bank. FCMB Group, Wema Bank Group, IBTC Chartered, Standard Chartered, AfribankGroup, Platinum- Habib, Diamond Bank, Unity Bank Group, Spring Bank, Skye Bank Group and First Inland Bank. The last group was the Alliance Bank group, which were mainly banks with very bad financials and very bad loan portfolio. They included fortune Bank, Liberty Bank, Triumph bank, Eagle, Metropolitan Bank, City Express Bank, and Gulf Bank. Some other banks were out rightly liquidated (Jakada\&Inusa, 2014).

A look at the new banks showed that Guaranty Trust Bank, Zenith Bank, Standard Chartered Bank Nigeria and Ecobank TransnationalNigeria 
did not merge with any bank but stood alone. Stanbic/IBTC Bank is a merger of IBTC, Chartered, Stanbic and Regent Bank.First Bank Limited acquired MBC International and FBN Merchant Bank., while United Bank for Africa (UBA) acquired Standard Trust Bank and Trade Bank. Intercontinental Bankacquired Gateway Bank, Global Bank, and Equity Banks tobecome the Intercontinental Bank Group.

Oceanic Bank acquired International Trust Bank and retained the name Oceanic Bank. Platinum Habib arose from the merger of Platinum and Habib banks and Skye Bank acquired Prudent Bank, EIB International Bank, Bond Bank, Reliance Bank, and Co-operative Bank. Union Bank acquired Broad Bank and Universal Trust Bank. WemaBankmerged with Lead Bank and National Bank but retained the name Wema Bank(Ezeoha, 2007).

Unity Bank was the merger of Intercity Bank, First Interstate Bank Plc, Tropical Commercial Bank, Pacific Bank Limited, Centre Point Bank, SocieteBancaire, NNB International, and Bank of the North and New Africa Bank.The Sterling Bank group is made up of Trust Bank of Africa Plc, Magnum Trust Bank, NBM Bank, NAL Bank, and the Indo-Nigerian Bank. Access Bank acquired Marina International Bank and Capital International Bank. AfribankacquiredAfribank Merchant Bank Plc and Assurance Bank. Equatorial Trust Bank (ETB) merged with its sister bank, Devcom Merchant Bank. Diamond Bank acquired Lion Bank (Fieldwork, 2020).

FCMB group consist of First City Monument Bank, Co-operative Development Bank and NAMBL while Fidelity Bank merged with FSB International and Manny Bank. The First Inland Bank Group was the name given to banks that comprised of First Atlantic Bank, Inland Bank, NUB International Bank, and IMB International Bank, and Societe General Bank of Nigeria. Oceanic Bank took on International Trust Bank and Spring Bank was a combination of Citizen Bank, Guardian Express Bank, Omega Bank, Fountain Trust Bank and Trans International Bank (Fieldwork, 2020).

Table 2: State of Nigerian Banks Post Consolidation

\begin{tabular}{|l|l|c|}
\hline $\begin{array}{c}\text { Names of the new } \\
\text { Banks }\end{array}$ & \multicolumn{1}{|c|}{ Merging Banks } & $\begin{array}{c}\text { Post-Merger } \\
\text { Share } \\
\text { Capital } \\
\text { (N'bn) }\end{array}$ \\
\hline Access Bank & Access, Marina Intl and Capital Banks & 28.60 \\
Afribank & Afribank, Assurance Bank and Afribank Merchant & 29.00 \\
Bank PHB & Bankers International & 25.00 \\
Citibank-NIB & Platinum Bank and Habib Bank & 25.00 \\
Diamond Bank & Citibank Nigerian Limited and Nigerian International \\
Eco Bank & Bank & 33.26 \\
ETB & Diamond Bank and Lion Bank & 57.00 \\
FCMB & Stand Alone & 26.36 \\
\hline
\end{tabular}




\begin{tabular}{|l|l|r|}
\hline Fidelity Bank & FCMB, Co-operative Development and Nig & 29.00 \\
First Bank & American Banks & 44.60 \\
First Inland Bank & Fidelity, FSB and Manny Bank & 30.60 \\
Intercontinental Bank & First Bank, FBN Merchant Bank, MBC Intl Bank & \\
Oceanic Bank & First Atlantic Bank and Inland Bank PLC & 34.00 \\
Skye Bank & Stand Alone & 51.00 \\
Spring Bank & Intercontinental, Equity, Global and Gateway & 31.00 \\
Standard Chartered & Banks & 37.70 \\
Stanbic/IBTC & Oceanic Bank and International Trust Bank & \\
Sterling Bank & Cooperative Banks & 27.60 \\
UBA & Citizen bank, Guardian express, Omega, Fountain & 25.00 \\
Union Bank & Trust Bank and Trans International Bank & 26.60 \\
Unity Bank & StandAlone & 25.00 \\
& IBTC, Chartered, Regent banks. & 29.00 \\
Trust Bank of AfricaBank, Magnum Trust Bank, & 58.60 \\
Zemith Bank & NBM Bank, NAL Bankand Indo-Nigerian Bank. & \\
Alliance Group of & UBA, Standard Trust Bank, Trade Bank. & 30.60 \\
Banks & UBN, Broad Bank, UTB, UBN Merchant Bank & \\
& Intercity, Interstate, Tropical, Pacific, Centre point & \\
& Banks, SocieteBancaire, NNB International, Bank of & 35.00 \\
the North and New African Bank & 38.00 \\
& Wema Bank, Lead Bank and National Bank & \\
& Stand Alone & \\
& Fortune Bank, Liberty Bank, Triumph Bank, Eagle & \\
& Bank, Metropolitan Bank, City Express Bank, Afex & \\
& Bank, Assurance Bank,Fountain Bank, Societe & \\
\hline
\end{tabular}

Source: Nigerian Fact Book 2009

The code of corporate governance was introduced in 2006 to checkmate the excesses of the banks. It was introduced soon after the consolidation of banks. For some banks, some problems became obvious almost immediately after the consolidation. The inherent problem was the continuous steep competition among the banks for dominance in the market place. Out of the 26 banks after the consolidation exercise in 2006, nine of them are no longer in operation (Ezeoha, 2007). The banks include:

\section{Alliance Bank Group}

The Alliance Bank Group was formed following a merger of eleven weak banks merged after consolidation in 2006. However, because of the huge liability position and debt portfolio, the Alliance Group of Banks was liquidated in 2006 almost immediately after the consolidation of banks.

\section{First Inland Bank Limited (Finbank)}

The First Inland Bank Group was established in 2006, as a merger of First Atlantic Bank, Inland bank Plc, NUB International Bank Limited, and 
IMB International Bank in 2008. The banks were rebranded as Finbank in 2009. However, in 2012, the rebranded Finbank could not operate profitably andFirst City Monument Bank of Nigeria later acquired the failed bank (Ezeoha, 2007). FCMB is still in operation up until today.

\section{Platinum-Habib Bank PLC (Bank PHB).}

Bank PHB came into being in 2005 because of the merger between Platinum Bank andHabib bank. After operating for some time, the newly merged banks suffered huge financial losses. To salvage the bank, the CBN created a bridgebankcalledKeystone bank. The bridge bank acquired the assets and liabilities of Bank PHB and the license was revoked thereafter.

Unfortunately, the bridge bank; Keystone Bank, also started having problems and the bank was subsequently taken over by Assets Management Corporation ofNigeria (AMCON) in 2011.AMCON brought in new management and injected more capital for the operation of the bank. In 2017, AMCON sold Keystone bank to new investors, Messrs Sigma Golf-Riverbank Consortium, for $\mathrm{N} 25 \mathrm{bn}(\$ 181.5 \mathrm{~m})$. The investors retained the bank as Keystone Bank, and the bank as operated successfully since then (Fieldwork, 2020).

\section{Oceanic Bank PLC}

The initial owners of Oceanic bank whichwas incorporated in 1990 were the Ibrufamily.In2010; the former Managing Director of the bank was found to have fraudulently misappropriated the depositors' funds and was reckless in granting loans. The CBN took over the banks until EcoBank Transnational Incorporated Bank later acquired it in 2011.

\section{Afribank Nigeria Limited}

Afribank bank Nigeria Limited was one of the oldest banks in Nigeria, incorporated in 1959 under the name Banque International Pour L'AfriqueOccidentale (Kolapo, Ajayi \&Aluko, 2016). The bank failed in 2011 and was acquired byMainstreet Bank Limited. Mainstreet bank was a bridge bank specially created by the $\mathrm{CBN} / \mathrm{AMCON}$ to acquire the assets and liabilities of Afribank.

However, after the acquisition of Afribank in 2011, Mainstreet bank was unable to meet customers' obligations and in 2014, Skye bank PLC acquired the bank. By 2018, unfortunately however, Skye bank, under the pressure of huge non-performing loans and inability to meet capital adequacy ratios for an extended period of time was taken over byCBN and a bridge bank named Polaris Bank was set up to manage the affairs of the distressed bank. Polaris Bank was set up by the CBN with the intention that AMCONwill 
recapitalize it in readiness for disposal for interested investors at the appropriate time.

\section{Equatorial Trust Bank PLC (ETB)}

Equatorial Trust Bank was a privately owned bank prior to 2009.ETB was established in 1990, it was a private bank. During the consolidation of banks in 2006, ETB merged with Devcom Merchant Bank a sister company owned by the same shareholders. In 2009, the CBN bailed out the bank when it started showing signs of distress (Ugoani, 2012). When the situation persisted, in 2011 after the injection of funds by AMCON, Sterling bank acquired the Equatorial Trust Bank.

\section{Intercontinental Bank PLC}

Intercontinental Bank was incorporated in 2002. It merged with three other banks; Equity bank, Gateway Bank, and Global bank during the consolidation in 2006. However, in 2013, the managing director of the bank was said to have used the depositors' funds to fund fictitious transaction to the tune N179bn (Fieldwork, 2020). The MD was removed and Access bank acquired the bank in 2013.Before the acquisition, Intercontinental Bank PLC was one of the biggest banks in the country. It had significant presence in Ghana and had many flourishing subsidiaries. However, quite a number of cases are pending in the court over the acquisition of the bank by the CBN.

\section{Diamond Bank PLC}

Diamond bank was incorporated as a private bank in 1990 with a private US equity firm, Carlyte, which owned 17.5 percent stake(Kolapo, Ajayi\&Aluko, 2017).In2018, the debt portfolio of the bank was huge and the bank became insolvent. Access Bank acquired the bank in 2018. Unlike previous acquisitions that were imposed by the regulator, the acquisition was at the instance of Diamond Bank.

It is now clear that out of twenty-six banks in 2006, nine of them have folded up. In a proactive bid to curb the rising issue of distress in the banking industry, the CBN introduced the concept of the bridge banks. The number of bridge banks currently operating in the country are two namely Keystone bank and Polaris Bank. One of the bridge banks, Mainstreet bank, has folded up to pave way for yet another bridge bank, Polaris Bank.

To ensure that the banking needs of the Nigerian populace are adequately met the $\mathrm{CBN}$ had issued new banking licenses. Five new commercial banks were licensed namely: Heritage Bank, Titan Trust Bank, Globus Bank,Suntrust Bank Nigeria Limited andProvidus Bank. In addition, five new merchant banks were licensed. They are; Coronation Merchant Bank, FSDH Merchant Bank, Rand Merchant Bank and Nova Merchant Bank.In 
addition, two non-interest banks licensed were;Jaiz Bank and TAJ Bank (Field work, 2020).

Table 3: List of Banks in Operation in Nigeria

\section{Commercial Banks with International Authorization} Name of Banks

1 Access Bank Plc

2 Fidelity Bank Plc

3 First City Monument Bank Limited

4 First Bank of Nigeria Limited

5 Guaranty Trust Bank Plc

6 Union Bank of Nigeria Plc

7 United Bank for Africa Plc

8 Zenith Bank Plc

Authorized Share Capital N50 Billion

N50 Billion

N50 Billion

N50 Billion

N50 Billion

N50 Billion

N50 Billion

N50 Billion

Commercial Banks with National Authorization

Name of Banks

9 Citibank Nigeria Limited

10 Ecobank Nigeria Plc

11 Heritage Banking Company Limited

12 Keystone Bank Limited

13 Polaris Bank Limited

14 Stanbic IBTC Bank Plc

15 Standard Chartered

16 Sterling Bank Plc

17 Titan Trust Bank Limited

18 Unity Bank Plc

19 Wema Bank Plc

Commercial Banks with Regional Authorization Name of Banks

20 Globus Bank Limited

21 SunTrust Bank Nigeria Limited

22 Providus Bank Limited

\section{Non-Interest Banks}

23 Jaiz Bank Plc

24 TAJ Bank Limited

\section{Merchant Banks}

25 Coronation Merchant Bank

26 FBNQuest Merchant Bank

27 FSDH Merchant Bank

28 Rand Merchant Bank

29 Nova Merchant Bank

Source: Field work, 2020

\author{
Authorized Share Capital \\ N25 Billion \\ N25 Billion \\ N25 Billion \\ N25 Billion \\ N25 Billion \\ N25 Billion \\ N25 Billion \\ N25 Billion \\ N25 Billion \\ N25 Billion \\ N25 Billion
}

\author{
Authorized Share Capital \\ N10 Billion \\ N10 Billion \\ N10 Billion \\ Authorized Share Capital \\ N10 Billion \\ N10 Billion \\ Authorized Share Capital
N15Billion
N15Billion
N15Billion
N15Billion
N15Billion
}


The number of banks operating in the country is 29 , including commercial banks, merchant banks, and non-interest banks. Besides, there are eight hundred and ninety-eight microfinance banks, also rendering banking services mostly to the rural populace in the country (CBN Report, 2019).

\section{Introduction of Bridge Banks}

A bridge bank is an institution created by a national regulator or Central Bank, and NDIC to operates a failed bank. The bridge bank is put in place until the CBN finds a buyer that will take over the bank's operations in the interest of depositors and prevent liquidation that will have dire consequences on the banking sector that may undermine public confidence in the industry (Makanjuola, 2015). Succinctly put, bridge banks are special purpose vehicles created to absorb the assets and liabilities of a distressed bank to inject capital into the new bank to make it attractive to investors.

Because of the bridge bank's creation, the CBN/AMCON had been able to sell off Keystone bank; however, such successes were not recorded with Mainstreet Bank, a bridge bank that became insolvent and later metamorphosed into another bridge bank, Polaris Bank. The failure of the management of Mainstreet bank to reposition the bank after the financial intervention by the CBN/AMCON raises questions about the efficacy of the bridge banks.

However, a significant attribute of the bridge banks can be to ensure that the distressed banks' staff are not sacked immediately as the hybrid bank always absorbs them. This suggests that the regulatory authorities may have decided not to allow further bank foreclosures in the country to jeopardize the public's confidence in the banking sector (Ugwu, Ohakah\& Kalu, 2016). They have decided to create bridge banks before any bank's distressed position becomes evident to the banking public.

\section{Revised Code of Corporate Governance}

In 2014, the CBN introduced the revised code of corporate governance for banks, microfinance banks, and discount houses operating in the country. The revised code of corporate governance aims to align the code with current realities and global best practices and eliminate perceived ambiguities in the previous code. The revised code specified a quarterly submission of returns by banks on their compliance with the code (Afolabi\& Dare, 2015). Besides, Section 3.3 and 3.4 made provision for whistleblowing to be given to the stakeholders. The stakeholders are requested to bring to the CBN's attention any perceived abnormality in any bank's operations.

So far, the revised code had reduced the spate of bank distresses in the country (Tayo-Tiwo, 2020). The scary stories of bank distress have decreased drastically. The reasons are connected with the various measures that the CBN 
had adopted in ensuring that the banks comply with the code. The routine inspections of the banks are much more rigorous than they had been in the past. The CBN had also adopted measures at ensuring that the issue of bank distress in the country was brought to the barest minimum.

Some of the measures include comprehensive supervision, recruitment of skilled personnel, e-examination, board composition, board meetings, and special board committees. Other parameters used by the $\mathrm{CBN}$ include reclassifying banks, reviewing the penalty regime for non-compliance, and reducing shareholder influence. The measures also have defined duties of board members, right of stakeholders, and internal audit report. The CBN rigorously conducts the on-site and off-site investigation, and training and retraining (Tayo-Tiwo, 2020).

The CBN carries out a stress test in banks from time to time. A recent stress test conducted in 2018 revealed that some of the commercial banks had funding gaps. From the analysis, seven banks have funding issues for an average of 30 days, while nine banks had funding gaps for 31-90 days. However, the overall financial position of banks revealed a good part of N4.8trillion assets above liabilities.

Some banks could fail the 31-90 days stress test. The fact that some banks did not meet the 31-90 days stress test is an indication that their share capitals have been eroded. However, with the benefit of the 2006 consolidation exercise and other actions taken, the $\mathrm{CBN}$ regulators are better informed and are well equipped to handle such situations (Tayo-Tiwo, 2020).

\section{Conclusion}

This paper examined the history and causes of bank failures in Nigeria by assessing the genesis of the banking institution in Nigeria and the expanded role of the $\mathrm{CBN}$ to ensure the sector's stability.For this study, relevant publications of the $\mathrm{CBN}$ and the NDIC were reviewed andand past literature on the subject. Accordingly, content analysis method was employed in gathering the research data used in the study.

The study identified low regulatory environment, non-performing loans, and undercapitalization as the recurring themes and the major causes of bank failures. Findings revealed that some of the banks merged after the 2006 consolidation exercise in the banking sector had folded up. The situation has led to yet another round of distress in the Nigerian banking industry.

Accordingly, the code of governance was revised in 2014. New measures to curtail bank failures were introduced. fIn addition, the regulators, have significantly improved on their regulatory functions(Tayo-Tiwo, 2020). The rate of bank distress has reduced considerably. The regulatory authorities introduced bridge banks' concept to revitalize ailing banks and reduce the incidences of bank failures in Nigeria. 
After the consolidation of banks in 2006, the Central Bank of Nigeria has been able to curtail the spate of bank liquidations in Nigeria to a reasonable extent. The introduction of the code of corporate governance in 2006 and the amended code in 2014 have contributed mostly to the banking sector's success.

The CBN's new regulatory mechanisms have assisted the apex bank in identifying teething problems in the banking industry before they crystallize. Bridge banks have been introduced. In the case of bridge banks, the apex bank, the $\mathrm{CBN}$, inject funds into distress banks, take over management before they become toxic, and cause apprehensions in the marketplace. As soon as the banks are stabilized, they are sold off to willing buys by AMCON.

\section{References:}

1. Adegbite, O. (2012). Corporate governance in Ghana: The past, the present, and the future. Public and Municipal Finance, 1(2), 1-5. doi:10.1108/CG-11-2015-0150

2. Afolabi, A., \& Dare, A. (2015). Corporate governance in the Nigerian banking sector: Issues and challenges. European Journal of Accounting, Auditing, and Finance Research, 3(55), 64-89.

3. CBN Circular (2010). CBN scope, conditions and minimum standards for commercial banks regulation, No 01

4. Ezeoha, A. (2007) Structural effects of banking industry consolidation in Nigeria: A review. Journal of Banking Regulation 8,159-176. doi:10.1057/palgrave.jbr.2350044

5. Honoson, K.,Sakai, K., \& Kotaro, T.(2007).Consolidation of Banks in Japan: Causes and Consequences. NBER Working Paper No 13399,JELno G21,G34

6. Ikpefan, O., \&Ojeka, S. (2013). Corporate governance as a tool for curbing bank distress in Nigerian deposit money banks: Empirical evidence. Research Journal of Finance and Accounting, 4(13), 41-51. Retrieved from http://www.iiste.org

7. Jakada, B., \&Inusa, A. (2014). Corporate governance: A strategic tool for survival in the Nigerian Banking sector. Journal of Economic Development, Management, IT, Finance and Marketing, 6, 45-56. Retrieved from http://www.gsmi-ijgb.com/

8. Kolapo, F., Ajayi, L., \&Aluko, O. (2016). How is size related to profitability? Post-consolidation evidence from selected banks in Nigeria.International Journal of Finance \& Banking Studies, 5(4), 3038. doi:10.20525/ijfbs.v5i4.592

9. Kano, M., \&Tsutsui, Y. (2003). Geographical Segmentation in Japanese Bank Loan

10. Market. Regional Science and Urban Economics 33 (2), 157-174. 
11. Makanjuola Y. (2015) Resolution of recapitalization through bridge banks.In: Banking reform in Nigeria. PalgraveMacmillan Studies in Banking and Financial Institutions.doi:10.1007/978-1-137-49353-8_8

12. Nigeria Deposit Insurance Corporation.(2002) AnnualReport \& Statement of Accounts.

13. Nigeria Deposit Insurance Corporation. (2003) Annual Report \& Statement of Accounts.

14. Nigeria Deposit Insurance Corporation. (2004) Annual Report \& Statement of Accounts.

15. Okafor, A. (2019). Refocusing on the success enabling factors in mergers and acquisitions.European Scientific Journal 15(16), 172-190

16. Okafor, A.\&Fadul, J. (2019).Bank risks,regulatory interventions, and deconstructing the focus of credit risk.Research Journal of Finance and Accounting, 10(8), Doi:10.7176/RJFA/10-8-09

17. Omoijiade, P.0. (2016). Historical analysis as a diagnostic tool of corporate governance ailment in theNigerian banking sector.Journal of Finance and Bank Management, 4, (1)112124.doi:10.15640/jfbm.v4n1a8

18. Osemeke, L. \&Adegbite, E. (2016).Regulatory multiplicity and conflicts: towards a combined code on corporate governance in Nigeria. Journal of Business Ethics, 133, 431451.doi.10.1007/s/10551- 014-2405-3

19. Ozili, P.\&Uadiale,O. (2017).Ownership concentration and bank profitability. Future Business Journal 3(2)159-171.

Doi:10.1016/j.fbj.2017.07.001

20. Peek, J., \& Rosengren, S. (2005). Unnatural Selection: Perverse Incentives and the Misallocaion of Credit in Japan, American Economic Review 95(4), 1144-1166

21. Tayo-Tiwo, A.(2020). Exploring how Nigerian banks regulators enforce compliance with the code of corporate governance. European Scientific Journal 16 (4), 14-28. Doi:10.19044/esj.2020v16n4p14.

22. Ugwu, K. E, Ohakah, I. \&Kalu, A. (2016). Evaluation of the effect of commercial bank consolidation on economic growth: Evidence from Nigeria, 2006-2015. Management Studies and Economic Systems, 3 (2), 61-75.

23. Umanholen, O. (2015). Effect of the global financial meltdown on Nigerian banking industry and economy.Scientific\& Academic Publishing, 5(3), 63-89. doi:10.5923/j.mm20150503.01

24. Virginia, W. (2011). Evidence based library and information practice. Research Methods. 6 (4)

25. White, M.D., \& Marsh, E.E. (2006). Content analysis: A flexible methodology. Library Trends 55(1), 22-45 doi: 10.1353/lib.2006.0053 